Тернопільський національний медичний університет імені І. Я. Горбачевського МОЗ Украӥни

\title{
ІНТЕНСИФІКАЦІЯ СУЧАСНОГО ОСВІТНЬОГО ПРОЦЕСУ ЯК ФАКТОР ІНТЕЛЕКТУАЛЬНОГО, НАВЧАЛЬНОГО ТА ЕМОЦІЙНОГО НАПРУЖЕННЯ СТУДЕНТІВ
}

\author{
N. O. Hevkaliuk, V. Ya. Krupey, O. V. Skochylo \\ I. Horbachevsky Ternopil National Medical University \\ INTENSIFICATION OF THE MODERN EDUCATIONAL PROCESS \\ AS A FACTOR OF INTELLECTUAL, EDUCATIONAL \\ AND EMOTIONAL STRESS OF STUDENTS
}

\begin{abstract}
Анотація. У підготовці лікарів нової генерації сьогодні основний акцент робиться як на засвоєнні студентами знань, вмінь, навичок, формуванні професійної компетентності, так і на формуванні гармонійних, усебічно розвинутих особистостей, які мають позитивні, комфортні стосунки з соціумом. Ускладнення програми навчання, широке використання технічних засобів у сучасному освітньому процесі, інтенсифікація навчання, збільшення кількості інформації та підвищення вимог до якості навчання зумовлюють закономірне збільшення інтелектуального, навчального та нервово-психічного навантаження. Тривалий вплив інформаційних перенавантажень знаходить своє негативне відображення не лише на фізичному самопочутті людини, але й на її психологічному функціонуванні. У студентському віці молодь володіє великими можливостями для напруженої розумової праці, цей період є заключним етапом вікового розвитку психофізіологічних і рухових можливостей організму. Адаптацію студентів до навчання у закладі вищої освіти - одну з фундаментальних міждисциплінарних наукових проблем необхідно розглядати як динамічний, багатосторонній і комплексний процес, що став предметом особливої уваги педагогів, психологів, медиків. Унаслідок емоційної нестабільності, стресових ситуацій, що призводять до неврологічних та рухових розладів, згідно з нейрогенною теорією, часто виникає бруксизм, чому сприяють і різноманітні відхилення в будові та функціях зубощелепної системи. Мета дослідження полягає в оцінці нервово-емоційного напруження студентів у період екзаменаційної сесії та виявленні відхилень, пов’язаних із психоемоційним станом студентів, у функціях зубощелепної системи. Ми провели клінічне стоматологічне обстеження за загальноприйнятими методиками 165 студентів віком від 20 до 25 років на кафедрі дитячої стоматології Тернопільського національного медичного університету імені І. Я. Горбачевського МОЗ України. Для встановлення типу темпераменту було проведено анкетування за опитувальником Г. Айзенка; для встановлення психоемоційного стану - анкетування з використанням опитувальника Г. Айзенка та PS шкал Міннесотського багатомірного особистісного опитувальника; для оцінки особистісної шкали проявів тривоги - опитувальник I. Теуlor. Діагностику наявності та оцінку ступеня вираженості бруксизму здійснювали за допомогою BruxChecker ${ }^{\circledR}$. Ми застосували алгоритм вибору оптимального методу лікування, направленого на усунення етіологічного фактора - психоемоційної нестабільності з урахуванням психофізіологічних особливостей конкретного випадку та стоматологічне лікування відхилень у функціях зубощелепної системи. Проведені нами дослідження доводять ефективність лікування бруксизму у випадку діагностичного визначення превалюючого етіологічного фактора та впливу саме на нього, що приводить до нормалізації всіх інших факторів.
\end{abstract}

Ключові слова: інтенсифікація навчання; нервово-емоційні напруження; психоемоційні особливості студентів; бруксизм.

Abstract. In the training of doctors of the new generation today the main emphasis is placed on the acquisition of students' knowledge, skills, skills, professional competence, and the formation of harmonious, well-developed individuals who have positive, comfortable relationships with society. The complexity of the curriculum, the widespread use of technical means in the modern educational process, the intensification of learning, increasing the amount of information and increasing requirements for the quality of education cause a natural

() Н. О. Гевкалюк, В. Я. Крупей, О. В. Скочило 
increase in intellectual, educational and mental load. The long-term impact of information overload is negatively reflected not only on a person's physical well-being, but also on his psychological functioning. During the student age, young people have great opportunities for intense mental work, this period is the final stage of age-related development of psychophysiological and motor abilities of the body. Adaptation of students to higher education - one of the fundamental interdisciplinary research problems - should be considered as a dynamic, multifaceted and complex process that has become the subject of special attention of teachers, psychologists, physicians. Due to emotional instability, stressful situations that lead to neurological and motor disorders, according to neurogenic theory, bruxism often occurs, which is facilitated by various deviations in the structure and function of the dental and maxillofacial system. The purpose of the study is to assess the nervous and emotional stress of students during the examination session and to identify abnormalities associated with the psycho-emotional state of students in the functions of the dental and maxillofacial system. We conducted a clinical dental examination according to the generally accepted methods of 165 students aged 20 to 25 years at the Department of Pediatric Dentistry of I. Horbachevsky Ternopil National Medical University. To determine the type of thermometer, a survey was conducted on the questionnaire of G. Eisenko; to establish the psycho-emotional state - a questionnaire using the G. Eisenko questionnaire and PS scales of the Minnesota Multidimensional Personality Questionnaire; to assess the personal scale of anxiety - questionnaire I. Teylor. Diagnosis of the presence and assessment of the severity of bruxism was performed using BruxChecker®. We have used an algorithm for selecting the optimal method of treatment aimed at eliminating the etiological factor - psycho-emotional instability, taking into account the psycho-physiological characteristics of the case and dental treatment of disorders of the dental system. Our research proves the effectiveness of treatment of bruxism in the case of diagnostic determination of the prevailing etiological factor and the impact on it, which leads to the normalization of all other factors.

Key words: learning intensification; nervous and emotional stress; psycho-emotional features of students; bruxism.

Вступ. За даними Всесвітньої організації охорони здоров'я та інших міжнародних і вітчизняних організацій охорони здоров'я, моніторингових досліджень науковців у різних країнах світу, фіксується зниження рівня здоров'я населення, що виявляється в погіршенні адаптації до щоденних психічних та фізичних навантажень. У реаліях сьогодення людина на різних етапах свого життєвого шляху все частіше стикається з дією різного роду стресорів, таких, як процеси урбанізації, несприятливий стан навколишнього середовища, прискорення загального темпу життя на фоні економічної та соціальної нестабільності, інформаційні перенавантаження тощо, тривалий вплив яких знаходить своє негативне відображення не лише на фізичному самопочутті людини, але й на ї̈ психологічному функціонуванні [1, 18].

В умовах соціально-економічної нестабільності, зокрема в умовах постійної трансформації освітньої системи, яку переживає Україна протягом останнього десятиріччя, внаслідок значної поширеності стресових ситуацій спостерігається збільшення кількості випадків психічних розладів із збільшенням ступеня їх важкості.

Змінюються орієнтири вищої освіти - поряд із підготовкою висококваліфікованих фахівців одним із провідних завдань вищої школи стає забезпечення умов для реалізації потенціалу студентів, надання їм підтримки для майбутньої самореалізації та збереження психічного здоров'я $[4,15]$. Водночас освітній простір закладу вищої освіти характеризується постійним зростанням обсягу наукової інформації, де навчання відноситься до категорії специфічної розумової праці, що потребує постійного активного напруження інтелектуальних, емо- ційних та вольових функцій студентів, актуалізації їх адаптаційних можливостей [1].

Встановлення карантину та карантинні обмеження на території більшості країн світу, в тому числі в Україні, про які йдеться в Постанові Кабінету Міністрів України «Про встановлення карантину з метою запобігання поширенню на території України гострої респіраторної хвороби COVID-19, спричиненої коронавірусом SARS-CoV-2, та етапів послаблення протиепідемічних заходів» [19], стали новим викликом для системи освіти в більшості країн світу. Глобальні програми медичної освіти (Global health education - GHE) залучають студентів до розуміння здоров'я та пов'язаних із ним проблем. Оскільки в ситуації, що виникла у зв'язку з пандемією коронавірусу COVID-19, було заборонено відвідування закладів освіти здобувачами на всій території країни, традиційні методи та способи навчального процесу були не в змозі забезпечити досягнення поставленої педагогічної мети, то виникла гостра необхідність у застосуванні комп’ютерних технологій [43]. На етапі карантинних обмежень роль інформаційно-комунікаційних технологій у розвитку освіти значно зросла, що потребувало запровадження дистанційних форм навчання в закладах освіти, тому стало необхідним використання хмарних сервісів та он-лайн ресурсів у навчальному процесі $[9,39,41]$. Дистанційне навчання в ТНМУ в період пандемії коронавірусу COVID-19 дозволило студентам не тільки продовжити вивчення навчального предмета згідно з силабусом дисципліни, але й опанувати знання, вміння та навички, необхідні сучасним фахівцям.

Однак ускладнення програми навчання, широке використання технічних засобів в освітньому про- 
цесі, інтенсифікація навчання, збільшення кількості інформації та підвищення вимог до якості навчання зумовлюють закономірне збільшення навчального та нервово-психічного навантаження [4, 20]. У студентському віці молодь володіє великими можливостями для напруженої розумової праці, цей період є заключним етапом вікового розвитку психофізіологічних і рухових можливостей організму, він характеризується інтенсивною роботою над формуванням своєї особистості та виробленням стилю поведінки $[1,8]$. Студентський вік - це особливий період у розвитку особистості як за «кризовою насиченістю» (екзаменаційні стреси, вікові проблеми, усвідомлення змісту професійної діяльності, ін.), так і за насиченістю можливостей максимального розвитку здібностей і потенціалу особистості [7].

Навчання у вищій школі потребує від студентів значних інтелектуальних та нервово-емоційних напружень, що сягають у період екзаменаційної сесії найвищої межі $[14,21]$. Крім цього, ці напруження, поєднуючись із соціальними, побутовими, екологічними та іншими факторами, можуть призвести до різних функціональних та психічних зривів [15, 21].

Студентське життя створює безліч психологічних труднощів і вимагає від молоді активізації всіх внутрішніх резервів, для того щоб своєчасно адаптуватися до нових умов життєдіяльності. Пошук закономірностей і механізмів адаптації студентів до навчання у ЗВО неминуче приводить до необхідності аналізу всього комплексу факторів, що визначають особливості навчальної діяльності студентів [8, 15]. Питання адаптації одне $з$ фундаментальних міждисциплінарних наукових проблем, що вивчається на педагогічному, психологічному, медико-біологічному та інших рівнях [14]. Адаптацію студентів до навчання у закладі вищої освіти необхідно розглядати як динамічний, багатосторонній і комплексний процес формування навичок задоволення тих вимог, що пред’являються до студента в період навчання та виховання у вищій школі.

До показників ефективності процесу адаптації слід віднести стабільність функціонального стану організму студента - відсутність різнопланових порушень психофізіологічних функцій, відсутність яскраво виражених ознак втоми при занятті навчальною діяльністю, відсутність емоційних порушень, належне засвоєння навчального матеріалу, навчальну успішність. Доведено, що основ- ною психологічною умовою реалізації та розвитку особистості є наявність інтересу до діяльності, і залежно від того, як реалізуються потенційні психологічні можливості студента, визначається професійний рівень майбутнього спеціаліста [5, 27].

Порушення процесу адаптації студентів до навчальної діяльності обумовлене тим, що роки навчання в університеті вважаються особливо напруженими, процес навчання відбувається в умовах інформаційного та емоційного стресу, значного психічного та фізичного напруження [3, 8]. Порушення процесу адаптації стає додатковим фактором виникнення стресу, тривожності чи агресивності, які не тільки не сприяють адаптації, але й ставлять під сумнів навчальну успішність [8, 22]. Згідно з сучасними уявленнями, стрес можна визначити як феномен, що виникає при порівнянні вимог, які ставляться перед особистістю, з іï здатністю справитися 3 ними $[3,18]$. Подолання стресу включає фізіологічні та психологічні механізми, тобто пізнавальні та поведінкові стратегії.

Надмірне напруження компенсаторно-пристосувальних механізмів, пов’язане зі сприйняттям та обробкою великого обсягу інформації, додаткове виконання значного обсягу позааудиторної роботи, емоційно-стресові ситуації, що супроводжуються проведенням контрольних заходів, негативно позначаються на стані психічного та соматичного здоров’ я студентів [20, 28]. Доведено, що емоційностресові ситуації суттєво впливають на динаміку адаптаційних процесів, на стан здоров'я людини [40]. Емоційно-стресові ситуації значно впливають на функціональну діяльність регуляторно-адаптаційних систем організму, які відіграють провідну роль в обмінних процесах та адаптаційно-трофічних реакціях організму [2].

На сьогодні вчені довели, що часті стресові ситуації, психоемоційна нестабільність $є$ провідним фактором у виникненні бруксизму, що виникає як відповідь на подразнення центральної нервової системи та асоціюється 3 деякими психічними та неврологічними захворюваннями [12, 35, 36]. В сучасному світі бруксизм є поширеною патологією, показник якої коливається від 10 \% у дорослих до 50 \% у дітей. Психосоматику бруксизму - періодичних нападів скреготіння зубами, що супроводжуються стрімким скороченням щелепних жувальних м’язів, пов'язують із безсвідомими процесами, які проявляються у більшості людей в нічний час, однак дещо рідше скреготіння зубів може відбуватись і в стані бадьорості [31, 32, 34, 35, 38]. 
Як показали дослідження останніх десятиліть, під час сну активність коркових і таламічних нейронів не тільки не припиняється, але в ряді випадків навіть збільшується [26]. Сигнали, які надходять у мозок, зазнають множинної трансформації на синапсах, перш ніж виявиться можливою формування вихідної реакції. Як результат змін збудливості коркових нейронів і порушень корково-підкоркових відношень можуть відбуватися порушення сну, викликані як фізіологічними, так і психологічними причинами, в тому числі й стресом [21, 22, 31].

Відомо, що стресорна реакція - це лише частина набагато складнішої реакції, відомої як загальний адаптаційний синдром Сельє [23]. Стрес як класична неспецифічна реакція в описанні Г. Сельє лише одна з реакцій, що складає загальну періодичну систему неспецифічних адаптаційних реакцій організму, які реагують на різні за величиною подразники і викликають коливання гомеостазу нормальних показників [25]. Звичайно, стрес часто призводить до стану психофізіологічної дезадаптації, на фоні якої можуть розвиватися різноманітні захворювання [20].

Інтенсивність впливу стресорних факторів суттєво відображається на такій характеристиці особистості, як реактивна (ситуативна) тривожність, підвищення рівня якої свідчить про наявність емоційного стресу [18], а високі показники особистісної тривожності корелюють із емоційними та психосоматичними захворюваннями [27]. Лікарстоматолог Кеннет Р. Гольян стверджує: «Скреготання зубами - це часто запрограмована реакція на стрес» [цит. за 36]. Згідно з нейрогенною теорією, ця патологія виникає в результаті порушення функцій центральної та периферичної нервової систем внаслідок емоційної нестабільності, стресових ситуацій, частих афектних станів, що призводить до неврологічних та рухових розладів [11].

Виникненню бруксизму, $з$ точки зору стоматологічної теорії, сприяють різноманітні відхилення в будові та функціях зубощелепної системи, зокрема патології прикусу, аномалії зубних рядів, неадекватно підібрані ортопедичні та ортодонтичні конструкції, артрит й артроз скронево-нижньощелепного суглоба та його дисфункції, посттравматичні зміни щелепно-лицевої ділянки, ін. [12, 17, 33, 37, $38,40,42]$. Оскільки бруксизм $є$ не тільки фізіологічним порушенням, але й психологічною проблемою, він потребує комплексного лікування [6, 24, 30, 34]. Лікарі-стоматологи протягом кількох десятиліть призначають пацієнтам використання особливих пристосувань, які запобігають скреготінню зубами, а також проводять корекцію прикусу зубів [29]. В останні роки широке застосування отримали інші терапевтичні підходи, які сприяють усуненню больових відчуттів і запобігають наслідкам скреготіння зубів [6, 31, 32].

Тривалий час вважалось, що лікувати бруксизм необхідно тільки стоматологічними методами, але, як показав проведений ретроспективний аналіз результатів лікування, така тактика є малоефективною та потребує додаткових маніпуляцій. У першу чергу, лікування повинно бути направлено на усунення етіологічного фактора, зокрема психоемоційної нестабільності [30, 36]. Також слід враховувати психофізіологічний статус особистості, який відіграє суттєву роль у процесах психологічної адаптації людини після перенесеного стресу різного характеру [3, 5, 13].

Основними проявами стану дезадаптації у студентів $є$ психофізіологічні - зниження розумової працездатності, порушення пам'яті, зниження продуктивності уваги, підвищена втомлюваність, зниження швидкості переробки інформації, більший період сенсомоторної реакції та низькі показники координації при значному погіршенні описаних показників під впливом фізичного навантаження [3, 13]. Погіршення фізичного та психічного здоров’я студентів, що констатуються останнім часом, зниження стресостійкості стали предметом особливої уваги педагогів, психологів, медиків.

На сьогодні доведено, щоб ефективно справлятися зі стресовою ситуацією та мати можливість нею керувати, важливо використовувати адекватні психотерапевтичні прийоми. Лікування бруксизму як фізіологічного та психологічного порушення передбачає корекцію поведінки з урахуванням психоемоційної особливості конкретного випадку і стоматологічне лікування [16, 32, 35, 37, 40]. Оскільки до даного часу не існує чіткого алгоритму постановки діагнозу та вибору оптимального методу лікування бруксизму, то актуальним $є$ проведення даного дослідження.

Мета дослідження полягає в оцінці нервовоемоційного напруження студентів у період екзаменаційної сесії та виявленні відхилень, пов’язаних із психоемоційним станом студентів, у функціях зубощелепної системи.

Методи дослідження. Для розв'язування поставлених у роботі завдань були використані такі наукові методи: а) теоретичні - аналіз психологопедагогічної наукової літератури для з'ясування 
питань ролі нервово-емоційного напруження студентів у розвитку бруксизму, узагальнення вітчизняного та зарубіжного досвіду застосування корекції поведінки з урахуванням психоемоційної особливості конкретного випадку, медикаментозної терапії, стоматологічного лікування; б) емпіричні - педагогічні спостереження за навчальною діяльністю суб’єктів середовища із використанням анкетування за опитувальником Г. Айзенка; для встановлення психоемоційного стану - анкетування з використанням опитувальника Г. Айзенка та PS шкал Міннесотського багатомірного особистісного опитувальника; для оцінки особистісної шкали проявів тривоги - опитувальник I. Teylor; в) статистичні - описові статистики для аналізу та інтерпретації результатів дослідження.

Результати дослідження. Ми провели клінічне стоматологічне обстеження 165 студентів віком від 20 до 25 років за загальноприйнятими методиками на кафедрі дитячої та хірургічної стоматології Тернопільського національного медичного університету імені І. Я. Горбачевського МОЗ України. Діагностику наявності бруксизму здійснювали за допомогою BruxChecker® для оцінки топографіï оклюзійних контактів, ступеня вираженості бруксизму; проводили визначення біоелектропотенціалів жувальних м’язів. Для встановлення типу темпераменту було проведено анкетування за опитувальником Г. Айзенка; для встановлення психоемоційного стану - анкетування з використанням опитувальника Г. Айзенка та PS шкал Міннесотського багатомірного особистісного опитувальника; для оцінки особистісної шкали проявів тривоги - опитувальник I. Teylor.

При визначенні типу темпераменту в 165 осіб встановлено превалювання збудженого холерика в 41,82 \% випадків (69 осіб), поширеність песимістичного меланхоліка та сангвінічно-флегматичного типу достовірно не відрізнялась (у 20,61 \% - 34 особи та 19,39 \% - 33 особи відповідно), що свідчить про превалювання іншого фактора у виникненні бруксизму. До основної групи увійшли 30 пацієнтів (18,18 \% випадків) із верифікованим діагнозом бруксизму із чітко вираженими проявами психоемоційної лабільності, що підтверджено визначенням темпераменту за опитувальником Г. Айзенка та результатами оцінки особистісної шкали проявів тривоги за опитувальником I. Teylor. У цій групі пацієнтів висока кореляційна залежність $(r=0,97, \mathrm{p}<0,05)$ спостерігається із ознаками темпераменту B і D типів, психоемоційний стан - тривожність В і Б типів.
Алгоритм обстеження та лікування пацієнтів із бруксизмом базувався на визначенні превалюючого етіологічного фактора та був спрямований на його усунення. Для пацієнтів основної клінічної групи, в етіології бруксизму яких превалювала психоемоційна лабільність, призначали седативну медикаментозну терапію за показаннями (спільно 3 психіатром).

Із анамнезу захворювання встановлено, що у всіх обстежених пацієнтів цієї клінічної групи, в етіології бруксизму яких превалює психоемоційна лабільність, відмічалось скреготання зубами під час сну; у 80,0 \% пацієнтів наявні хрускіт і біль у ділянці скронево-нижньощелепних суглобів, відмічають підвищену чутливість зубів; 76,67 \% пацієнтів страждали від головного болю, больових відчуттів у ділянці скронево-нижньощелепних суглобів при широкому відкриванні рота, відмічали скреготіння зубами навіть удень.

Ефективність проведеного лікування оцінювали через 12 місяців від початку лікування, оскільки в коротший термін спостереження недоцільно проводити моніторинг через тривалий реабілітаційний період у функціонуванні жувального та щелепнолицевого апарату. В основній клінічній групі відмічено достовірне зниження інтенсивності больових відчуттів у ділянці скронево-нижньощелепних суглобів, зокрема при широкому відкриванні рота, а також зменшення інтенсивності та частоти головного болю, зниження рівня гіперестезії зубів. Отримані клінічні результати підтверджені додатковими методами дослідження - результатами оклюзіограм, дослідженням за допомогою BruxChecker®, електроміографією жувальних м'язів та дослідженням психоемоційного стану. Однак слід сказати, що повного зникнення вказаних симптомів не відмічалося впродовж терміну спостереження.

При повторній оцінці (через 12 місяців) проявів особистісної тривоги в обстежених основної групи ми встановили достовірне зниження $(\mathrm{p}<0,05)$ всіх клінічних проявів. Так, лабільність нервової системи, зокрема хронічний страх, пов'язаний із тривожністю, сенситивністю, невпевненістю в собі, відмічали в 6,67 \% випадків (2 чол.). Лабільність вегетативної нервової системи в загрозливих ситуаціях визначалася в 20,0 \% випадків (6 чол.), розлади сну, пов’язані із загальним внутрішнім напруженням, - в 6,67 \% (2 чол.), почуття власної неповноцінності - у 3,33 \% (1 пацієнта цієї групи).

Отже, при переважанні психоемоційного фактора в етіології бруксизму (r=0,97, p<0,05) у студентів в 
емоційно-стресових ситуаціях, якими є проведення контрольних заходів у період екзаменаційної сесії, ефективною є його медикаментозна корекція, що приводить до зменшення проявів бруксизму та нормалізації психоемоційного стану пацієнтів. Ми запропонували алгоритм постановки діагнозу бруксизму та алгоритм вибору оптимального методу лікування, направленого на усунення етіологічного фактора - психоемоційної нестабільності з урахуванням психофізіологічних особливостей конкретного випадку, медикаментозну терапію, а також стоматологічне лікування різнопланових відхилень у будові та функціях зубощелепної системи.

Висновки та перспективи подальших досліджень. Проведені нами дослідження доводять ефективність лікування бруксизму у випадку діагностичного визначення превалюючого етіологічного фактора і впливу саме на нього, що приводить до нормалізації всіх інших факторів та зниження інтенсивності бруксизму. Надмірне напруження компенсаторно-пристосувальних механізмів, пов'язане зі збільшенням навчального і нервово-психічного навантаження студентів, сприйняттям та обробкою великого обсягу інформації, часті стресові ситуації, психоемоційна нестабільність, що є провідним фактором у виникненні бруксизму, потребує усунення етіологічного фактора, корекції поведінки з урахуванням психоемоційних особливостей, медикаментозної терапії, стоматологічного лікування.

Проведення даного дослідження не вичерпує всіх аспектів проблеми ролі нервово-психічного навантаження студентів в умовах трансформації освітньої системи як провідного етіологічного фактора виникнення бруксизму. Перспективними напрямами наукових розробок є пошук шляхів нормалізації компенсаторно-пристосувальних механізмів, психоемоційного стану студентів, пов’язаних із збільшенням навчального та нервово-психічного навантаження студентів в умовах значних інтелектуальних та нервово-емоційних напружень.

го закладу / О. І. Іванова, Л. М. Басанець // Педагогічні науки: теорія, історія, інноваційні технології. - 2008. № 3. - С. 335-343.

9. Карплюк С. О. Особливості цифровізації освітнього процесу у вищій школі / С. О. Карплюк // Інформаційноцифровий освітній простір України: трансформаційні процеси і перспективи розвитку : матеріали методологічного семінару НАПН України (Київ, 4 квітня 2019 р.). K., 2019. - С. 188-197.

10. Квашніна Л. В. Поняття адаптації і адаптованість як інтегральний показник здоров’я / Л. В. Квашніна // Перинатологія та педіатрія. - 2000. - № 1. - С. 33-36.

11. Клітинська О. В. Сучасні теорії етіології та патогенезу бруксизму / О. В. Клітинська, Т. І. Зорівчак // Молодий вчений. - 2017. - № 3 (43). - С. 82-85.

12. Клітинський Ю. В. Діагностика та комплексне патогенетичне лікування м'язево-суглобового больового дисфункційного синдрому / Ю. В. Клітинський // Наук. вісн. Нац. мед. ун-ту ім. О. О. Богомольця. - 2006. № 3. - С. 78-80.

13. Максименко С. Д. Загальна психологія / С. Д. Максименко. - К. : Центр учбової літератури, 2008. - 272 с.

14. Малахов П. С. Проблемність адаптації студентівмедиків / П. С. Малахов, Ю. О. Асєєва, А. С. Харітонова // Медична психологія. - 2016. - № 2. - С. 3-5.

15. Морозова Е. Н. Работоспособность и психологическое состояние студентов в течение учебного года и факторы, их определяющие / Е. Н. Морозова, Д. А. Жуйко, А. Л. Гринько // Слобожан. наук.-спорт. вісн. - 2009. № 3. - С. 307-310. 
16. Нетцель Ф. Практическое руководство по ортодонтической диагностике / Ф. Нетцель, К. Шульц. - Львов, 2006. - 175 с.

17. Павленко О. В. Електроміографічна оцінка функціональної активності жувальних м'язів у пацієнтів 3 ортопедичними конструкціями з опорою на імплантати / О. В. Павленко, В. І. Біда, О. М. Дорошенко // Соврем. стоматология. - 2012. - № 3. - С. 131-134.

18. Пасько О. М. Психологія : навч. посіб. / О. М. Пасько, О. М. Цільмак ; за заг. ред. О. М. Цільмак. - Одеса : Видавець Букаєв В.В., 2018. - 270 с.

19. Про встановлення карантину з метою запобігання поширенню на території України гострої респіраторної хвороби COVID-19, спричиненої коронавірусом SARS$\mathrm{CoV}-2$, та етапів послаблення протиепідемічних заходів : Постанова Кабінету Міністрів України від 9 грудня 2020 р. № 1236.

20. Психофізіологічні особливості станів дезадаптації у студентів-медиків в сучасних умовах / Г. М. Кожина, Д. І. Маракушин, К. О. Зеленська [та ін.] // Український журнал медицини, біології та спорту. - 2017. - № 1 (3). С. 91-95.

21. Пшук Н. Г. Роль психосоціальних чинників в ґенезі соціальної дезадаптації у студентської молоді / Н. Г. Пшук, Д. П. Слободянюк // Український вісник психоневрології. - 2015. - Т. 23, № 2 (83). - С. 86-91.

22. Самохвалов В. Г. Особенности адаптационных и восстановительных процессов у лиц молодого возраста с артериальной гипотонией / В. Г. Самохвалов, И. Н. Исаева, О. Д. Булынина // Клінічна та експериментальна медицина. - 2010. - № 4. - С. 103-107.

23. Селье Г. Очерки об адаптационном синдроме / Г. Селье. - М. : Медицина, 1972. - 122 с.

24. Смаглюк Л. В. Важливість комплексної стоматологічної допомоги в реабілітації пацієнтів із зубощелепними аномаліями / Л. В. Смаглюк, В. І. Смаглюк // Український стоматологічний альманах. - 2012. - № 5. С. 61-72.

25. Токаревич И. В. Общая ортодонтия : учеб.-метод. пособие / И. В. Токаревич. - Минск : БГМУ, 2015. - 80 с.

26. Фізіологія вищої нервової діяльності (ВНД) : навч. посіб. / [І. А. Іонов, Т. Є. Комісова, А. В. Мамотенко та ін.]. - Х. : ФОП Петров В.В., 2017. - 143 с.

27. Чепига М. П. Стимуляція здоров’я та інтелекту / М. П. Чепига, С. М. Чепига. - К. : Знання, 2006. - 346 с.

28. Чернобровкін В. М. Соціальні детермінанти розвитку психічного здоров' я студентської молоді / В. М. Чернобровкін, Ю. М. Ящишина // Mat. IX mezinarodni vedecko-prakticka konference «Zpravy vedecke ideje 2013». Psychologie a sociologie. - Praha : Publishing House «Education and Science» s.r.o., 2013. - S. 30-32.

29. Шмут Г. П. Ф. Практическая ортодонтия / Г. П. Ф. Шмут, Э. А. Холтгрейв, Д. Дрешер ; под ред. П. С. Флиса. - Львов : ГалДент, 1999. - 208 с.

30. Amir I. Bruxism secondary to antipsychotic drug exposure: A positive response to pro-pranolol / I. Amir,
H. Hermesh, A. Gavish // Clin. Neuropharmacol. - 2015. No. 20. - P. 86-89.

31. Baba K. Bruxism force detection by a piezoelectric film-based recording device in sleeping humans / K. Baba, G. Clark, T. Ohyama // Journal Oral Pain. - 2013. - No. 17. P. 58-64.

32. Bader G. Sleep bruxism: anoverview of anoromandibular sleep movement disorder / G. Bader, G. Lavigne // Sleep Medicine Revievs. - 2017. - No. 1 (1). - P. 27-43.

33. Bruxism: A Literature Review / S. Varalakshmi, M. Praveen Kumar, D. Sravanthi, Abdul Habeeb Bin Mohsin // Journal of International Oral Health. - 2014. No. 6 (6). - P. 105-109.

34. Controlled assessment of the efficacy of occlusal stabilization splints on sleep bruxism / J. Zaag, F. Lobbezoo, D. Wicks, C. Visscher // Journal Orofacial Pain. - 2015. No. 19. - P. 151-158.

35. Lavigne G. Neurobiological Mexhanisms involved in Sleep Bruxism / G. Lavigne, T. A. Kato, K. B. Sessle // Critical Reviews in Oral Biology and Medicine. - 2014. No. 65 (4). - P. 32-33.

36. Lobbezoo F. Etiology of bruxism / F. Lobbezoo, H. Hamburger, M. Naeije // Theory and Practice. Quintessence. - 2014. - No. 55. - P. 53-65.

37. Martits Y. M. The comparative analysis of masticatory muscles electromyographic activity in patients with orthodontic disorders and those with orthognatic bite / Y. M. Martits, I. R. Plavutska // Клінічна стоматологія. 2016. - № 3 (16). - C. 56-61.

38. Nishigawa K. Quantitative study of bite force during sleep associated bruxism / K. Nishigawa, E. Bando, M. Nakano // Journal Oral Rehabil. - 2015. - No. 28. P. 485-491.

39. Rose S. Medical student education in the time of COVID-19 / S. Rose // Academic Medicine Journal of the Association of American Medical Colleges. - 2020. No. 323 (21). - P. 2131-2132. DOI 10.1001/jama.2020.5227.

40. Safari A. Evaluation of the relationship between bruxism and premature occlusal contacts / A. Safari, Z. Jowkar, M. Farzin // J. Contemp. Dent. Pract. - 2013. No. 14 (4). - P. 616-621.

41. Stanton B. Medical Education in the Age of COVID-19 / B. Stanton // Academic Medicine Journal of the Association of American Medical Colleges. DOI 10.1097/ ACM.0000000000003890.

42. Türp J. C. The dental occlusion as a suspected cause for TMDs: epidemiological and etiological considerations / J. C. Türp, H. Schindler // J. Oral Rehabil. - 2012. Vol. 39 (7). - P. 502-512.

43. World Health Organization. Considerations for schoolrelated public health measures in the context of COVID-19. Access mode : https://www.who.int/publications/i/item/ considerations-for-school-related-public-health-measuresin-the-context-of-covid-19. 


\section{References}

1. Aleksyeyeva, T.V. (2008). Sotsialno-psykholohichni aspekty adaptatsii [Socio-psychological aspects of adaptation]. Donetsk: Veber [in Ukrainian].

2. Nakonechna, O.A., Yarmysh, N.V., Stetsenko, S.O., \& Martynova, S.M. (2021). Bioenerhetychni protsesy [Bioenergetic processes]. Kharkiv: KhNMU [in Ukrainian].

3. Bulah, V.P. (2014). Stres ta yoho vplyv na orhanizm lyudyny [Stress and its impact on the human body]. Materynstvo - Motherhood, 3, 10-15 [in Ukrainian].

4. Buslovskaya, L.K., \& Ryzhkova, Yu.P. (2009). Adaptivnyie vozmozhnosti orhanizma studientov i sposoby ikh povysheniya [Adaptive capabilities of the body of students and ways to increase them]. Visnyk Khark. nats. un-tu im. V. N. Karazina. Ser. «Valeolohiia: suchasnist $i$ maibutnie» - Visnyk VKarazin. Kharkiv. National University Serie "Valeology: Present and Future”, 862(6), 22-26 [in Russian].

5. Hubenko, I.Ya., Karnatska, O.S., \& Shevchenko, O.T. (2013). Osnovy zahalnoyi i medychnoyi psykholohiyi, psykhichnoho zdorovya ta mizhosobovoho spilkuvannya [Fundamentals of general and medical psychology, mental health and interpersonal communication]. Kyiv: Medytsyna [in Ukrainian].

6. Drohomyretska, M.S., \& Martyts, Yu.M. (2012). Doslidzhennya nichnoho bruksyzmu u ditey v period zminnoho prykusu z vykorystannyam BruxChecker [Study of nocturnal bruxism in children during the period of variable occlusion using BruxChecker]. Suchasna ortodontiya shlyakh profesiynoho rozvytku, mat. nauk.-prakt. konf. z mizhnar. uchastyu - Modern Orthodontics - the path of professional development, proceedings of the scientificpractical conf. with international participation. Kyiv [in Ukrainian].

7. Zoriy, A.I. (2010). Vzayemozvyazok osobystisnykh rys studentiv-medykiv i pokaznykiv vehetatyvnoyi nervovoyi systemy pid chas skladannya ispytiv [Relationship between personality traits of medical students and indicators of the autonomic nervous system during exams]. Medychna psykholohiya - Medical Psychology, 1,15-18 [in Ukrainian].

8. Ivanova, O.I., \& Basanets, L.M. (2008). Osoblyvosti adaptatsii studentiv-pershokursnykiv do navchannia $\mathrm{v}$ umovakh suchasnoho osvitnoho zakladu [Features of adaptation of first-year students to study in a modern educational institution]. Pedahohichni nauky: teoriia, istoriia, innovatsiini tekhnolohii - Pedagogical Sciences: Theory, History, Innovative Technologies, 3, 335-343 [in Ukrainian].

9. Karpliuk, S.O. (2019). Osoblyvosti tsyfrovizatsiyi osvitnoho protsesu u vyshchiy shkoli [Features of digitalization of the educational process in higher education]. Informatsiyno-tsyfrovyy osvitniy prostir Ukrayiny: transformatsiyni protsesy i perspektyvy rozvytku, mat. metodolohichnoho seminaru NAPN Ukrayiny - Information and digital educational space of Ukraine: transformation processes and prospects of development, proceedings of the methodological seminar of the National Academy of Pedagogical Sciences of Ukraine. Kyiv [in Ukrainian].

10. Kvashnina, L.V. (2000). Ponyattya adaptatsiyi i adaptovanist yak intehralnyy pokaznyk zdorovya [The concept of adaptation and adaptability as an integral indicator of health]. Perynatolohiya ta pediatriya-Perinatology and Pediatrics, 1, 33-36 [in Ukrainian].

11. Klitynska, O.V., \& Zorivchak, T.I. (2015). Suchasni teoriyi etiolohiyi ta patohenezu bruksyzmu [Modern theories of etiology and pathogenesis of bruxism]. Molodyy vchenyy - Young Scientist, 3(43), 82-85 [in Ukrainian].

12. Klitynskyi, Yu.V. (2006). Diahnostyka ta kompleksne patohenetychne likuvannia miazevo-suhlobovoho bolovoho dysfunktsiinoho syndromu [Diagnosis and complex pathogenetic treatment of musculoskeletal pain dysfunction syndrome]. Nauk. Visn. nats. med. un-tu im. O. O. Bohomoltsia - Scientific Bulletin of the Bogomolets National Medical University, 3, 78-80 [in Ukrainian].

13. Maksymenko, S.D. (2008). Zahalna psykholohiya [General Psychology]. Kyiv: Tsentr uchbovoyi literatury [in Ukrainian].

14. Malakhov, P.S., Asieieva, Yu.O., \& Kharitonova, A.S. (2016). Problemnist adaptatsiyi studentiv-medykiv [Problems of adaptation of medical students]. Medychna psykholohiya - Medical Psychology, 2, 3-5 [in Ukrainian].

15. Morozova, Ye.N., Zhuyko, D.A., \& Hrinko, A.L. (2009). Rabotosposobnost i psikhologicheskoye sostoyaniye studentov $\mathrm{v}$ techeniye uchebnogo goda i faktory, ikh opredelyayushchiye [Efficiency and psychological state of students during the academic year and the factors that determine them]. Slobozhanskyi naukovo-sportyvnyi visnyk - Slobozhansky Scientific and Sports Bulletin, 3, 307-310 [in Russian].

16. Nettsel, F., \& Shylts, K. (2006). Prakticheskoye rukovodstvo po ortodonticheskoy diagnostike [A practical guide to orthodontic diagnosis]. Lvov [in Russian].

17. Pavlenko, O.V., Bida, V.I., \& Doroshenko, O.M. (2012). Elektromiohrafichna otsinka funktsionalnoi aktyvnosti zhuvalnykh miaziv u patsiientiv z ortopedychnymy konstruktsiiamy z oporoiu na implantaty [Electromyographic assessment of functional activity of masticatory muscles in patients with orthopedic structures based on implants]. Sovremennaya stomatolohyya - Modern Dentistry, 3, 131134 [in Ukrainian].

18. Pasko, O.M., \& Tsilmak, O.M. (2018). Psykholohia [Psychology]. Odesa: vydavets Bukaiev V.V. [ in Ukrainian].

19. Postanova Kabinetu Ministriv Ukrayiny Pro vstanovlennya karantynu z metoyu zapobihannya poshyrennyu na terytoriyi Ukrayiny hostroyi respiratornoyi khvoroby COVID-19, sprychynenoyi koronavirusom SARS-CoV-2, ta etapiv poslablennya protyepidemichnykh zakhodiv vid 9 hrudnya 2020 r. № 1236 [Resolution of the Cabinet of Ministers of Ukraine On the establishment of quarantine to prevent the spread of acute respiratory disease COVID-19 caused by coronavirus SARS-CoV-2 and stages of mitigation 
of anti-epidemic measures dated December 9, 2020 No. 1236] [in Ukrainian].

20. Kozhyna, H.M., Marakushyn, D.I., Zelenska, K.O., Khaustov, M.M., \& Zelenska, H.M. (2017). Psykhofiziolohichni osoblyvosti staniv dezadaptatsiyi u studentivmedykiv v suchasnykh umovakh [Psychophysiological features of maladaptation states in medical students in modern conditions]. Ukrayinskyy zhurnal medytsyny, biolohiyi ta sportu - Ukrainian Journal of Medicine, Biology and Sport, 1(3), 91-95 [in Ukrainian].

21. Pshuk, N.H., \& Slobodianiuk, D.P. (2015). Rol psykhosotsialnykh chynnykiv u genezi sotsialnoyi dezadaptatsiyi u studentskoyi molodi [The role of psychosocial factors in the genesis of social maladaptation in student youth]. Ukrayinskyy visnyk psykhonevrolohiyi - Ukrainian Journal of Psychoneurology, 23, 2(83), 86-91 [in Ukrainian].

22. Samokhvalov, V.G., Isaeva, I.N., \& Bulynina, O.D. (2010). Osobennosti adaptatsionnykh i vosstanovitelnykh protsessov u lits molodogo vozrasta s arterialnoy gipotoniyey [Features of adaptation and recovery processes in young people with arterial hypotension]. Klinichna ta eksperymentalna medytsyna-Clinical and Experimental Medicine, 4, 103-107 [in Russian].

23. Sielie, G. (1972). Ocherki ob adaptatsionnom sindrome [Essays on adaptation syndrome]. Moscow: Mieditsyna [in Russian].

24. Smahliuk, L.V., \& Smahliuk, V.I. (2012). Vazhlyvist kompleksnoyi stomatolohichnoyi dopomohy v reabilitatsiyi patsiyentiv iz zuboshchelepnymy anomaliyamy [The importance of comprehensive dental care in the rehabilitation of patients with dental anomalies]. Ukrayinskyy stomatolohichnyy almanakh - Ukrainian Dental Almanac, 5, 61-72 [in Ukrainian].

25. Tokarievich, I.V. (2015). Obshchaya ortodontiya [General orthodontics]. Minsk: BGMU [in Russian].

26. Ionov, I.A., Komisova, T.Ye., Mamotenko, A.V., ... Katerynych, O.O. Fiziolohiya vyshchoyi nervovoyi diyalnosti (VND [Physiology of higher nervous activity (GNI)]. Kharkiv: FOP Petrov V.V. [in Ukrainian].

27. Chepyha, M.P., \& Chepyha, S.M. (2006). Stymulyatsiya zdorovya ta intelektu [Stimulating health and intelligence]. Kyiv: Znannia [in Ukrainian].

28. Chernobrovkin, V.M., \& Yashchyshyna, Yu.M. (2013). Sotsialni determinanty rozvytku psykhichnoho zdorovia studentskoi molodi [Social determinants of mental health development of student youth]. Mat. IX mezhnarodnivedeckopraktickakonference «Zpravyvedeckeideje-2013». Psychologie a sociologie: Praha. Publishing House «Education and Science» s.r.o. [in Ukrainian].

29. Shmut, G.P.F., Kholtgreyv, E.A., Dresher, D., \& Flis, P.S. (1999). Prakticheskaya ortodontiya [Practical orthodontics]. Lvov: GalDent [in Russian].
30. Amir, I., Hermesh, H., \& Gavish, A. (2015). Bruxism secondary to antipsychotic drug exposure: A positive response to pro-pranolol. Clin. Neuropharmacol., 20, 86-89.

31. Baba, K., Clark, G., \& Ohyama, T. (2013). Bruxism force detection by a piezoelectric film-based recording device in sleeping humans. Journal Oral Pain, 17, 58-64.

32. Bader, G., \& Lavigne, G. (2017). Sleep bruxism: anoverview of anoromandibular sleep movement disorder. Sleep Medicine Revievs, 1(1), 27-43.

33. Varalakshmi, S., Praveen Kumar, M., Sravanthi, D., \& Abdul Habeeb Bin Mohsin (2014). Bruxism: A Literature Review. Journal of International Oral Health, 6(6),105-109.

34. Zaag, J., Lobbezoo, F., Wicks, D., \& Visscher, C. (2015). Controlled assessment of the efficacy of occlusal stabilization splints on sleep bruxism. Journal Orofacial Pain, 19, 151-158.

35. Lavigne, G., Kato, T.A., \& Sessle, K.B. (2014). Neurobiological Mexhanisms involved in Sleep Bruxism. Critical Reviews in Oral Biology and Medicine, 65(4), 32-33.

36. Lobbezoo, F., Hamburger, H., \& Naeije, M. (2014). Etiology of bruxism. Theory and Practice.Quintessence, 55, 53-65.

37. Martits, Y.M., \& Plavutska, I.R. (2016). The comparative analysis of masticatory muscles electromyographic activity in patients with orthodontic disorders and those with orthognatic bite. Klinichna stomatolohiya - Clinical Dentistry, 3(16), 56-61.

38. Nishigawa, K., Bando, E., \& Nakano, M. (2015). Quantitative study of bite force during sleep associated bruxism. Journal Oral Rehabil., 28, 485-491.

39. Rose, S. (2020). Medical student education in the time of COVID-19. Academic Medicine Journal of the Association of American Medical Colleges, 323(21), 21312132. DOI 10.1001/jama.2020.5227.

40. Safari, A., Jowkar, Z., \& Farzin, M. (2013). Evaluation of the relationship between bruxism and premature occlusal contacts. J Contemp. Dent. Pract.,14(4), 616-621.

41. Stanton, B. Medical Education in the Age of COVID-19. Academic Medicine Journal of the Association of American Medical Colleges. DOI 10.1097/ ACM.0000000000003890.

42. Türp, J.C., \& Schindler, H. (2012). The dental occlusion as a suspected cause for TMDs: epidemiological and etiological considerations. J. Oral Rehabil., 39(7), 502-512.

43. World Health Organization. Considerations for schoolrelated public health measures in the context of COVID-19. Retrieved from: https://www.who.int/publications/i/item/ considerations-for-school-related-public-health-measuresin-the-context-of-covid-19. 